Short communication

\title{
Conodont index fossil Hindeodus changxingensis Wang fingers greatest mass extinction event
}

\author{
I. Metcalfe $^{\mathrm{a}, *}$, R.S. Nicoll ${ }^{\mathrm{b}}$, B.R. Wardlaw ${ }^{\mathrm{c}}$ \\ a Asia Centre, University of New England, Armidale, NSW 2351, Australia \\ ${ }^{\mathrm{b}}$ Department of Earth \& Marine Sciences, Australian National University, Canberra, ACT 0200, Australia \\ ${ }^{\mathrm{c}}$ U.S. Geological Survey, 926A National Centre, Reston, VA 20192-0001, USA
}

Received 17 June 2006; received in revised form 26 September 2006; accepted 4 January 2007

Available online 6 February 2007

\begin{abstract}
The marine conodont fossil species, Hindeodus changxingensis Wang, that has a distinctive morphology, is restricted to a very narrow stratigraphic interval essentially from the Permian-Triassic extinction event through the internationally recognized boundary and into the very earliest Triassic. The species is geographically widespread in the Tethyan Region, from Italy to South China, and serves as a characteristic index fossil to reliably identify this short but critical interval that encompasses the greatest mass extinction of life on earth and the boundary between the Paleozoic and Mesozoic Eras.
\end{abstract}

(C) 2007 Nanjing Institute of Geology and Palaeontology, CAS. Published by Elsevier Ltd. All rights reserved.

Keywords: Conodont; Index fossil; Permian-Triassic boundary; Mass extinction

\section{Introduction}

The greatest catastrophic loss of life, known as the "mother of all" mass extinctions (Erwin, 1993, 1994; Benton, 2003) occurred very slightly before the internationally defined Permian-Triassic (P-T) boundary (Yin et al., 2001; Jin et al., 2000), and is dated at $252.6 \pm 0.2$ million years ago (Mundil et al., 2004), see Fig. 1. This event resulted in approximately $95 \%$ of organisms on earth, at the species level, being wiped out. Precise age control and correlation with the internationally defined P-T boundary in China underpins all studies of this important mass extinction. We here propose the

\footnotetext{
* Corresponding author. Tel.: +61 267733499; fax: +61 267727136 E-mail addresses: imetcal2@une.edu.au (I. Metcalfe), bnicoll@goldweb.com.au (R.S. Nicoll), bwardlaw@usgs.gov (B.R. Wardlaw).
}

marine conodont fossil species, Hindeodus changxingensis Wang, that has a distinctive morphology, is easily identified, is restricted to a very narrow stratigraphic interval that marks the P-T boundary and mass extinction level, as a characteristic marker index fossil for the greatest mass extinction event known to science.

The Pa element of Hindeodus changxingensis (Fig. 2) is characterized by a much fused carinal ridge and was initially considered a possible rare aberrant pathogenic feature of another older species, Hindeodus julfensis. Within the narrow interval between extinction event and the recognized Permian-Triassic boundary, we find Hindeodus changxingensis common, with a very narrow range, generally $30-100 \mathrm{~cm}$ in most sections (Fig. 3) and we can now demonstrate a growth sequence which validates the species. A synonomy and short formal diagnosis is provided below.

Correlation tools available from CHRONOS and Paleostrat provided quantitative stratigraphic correla- 


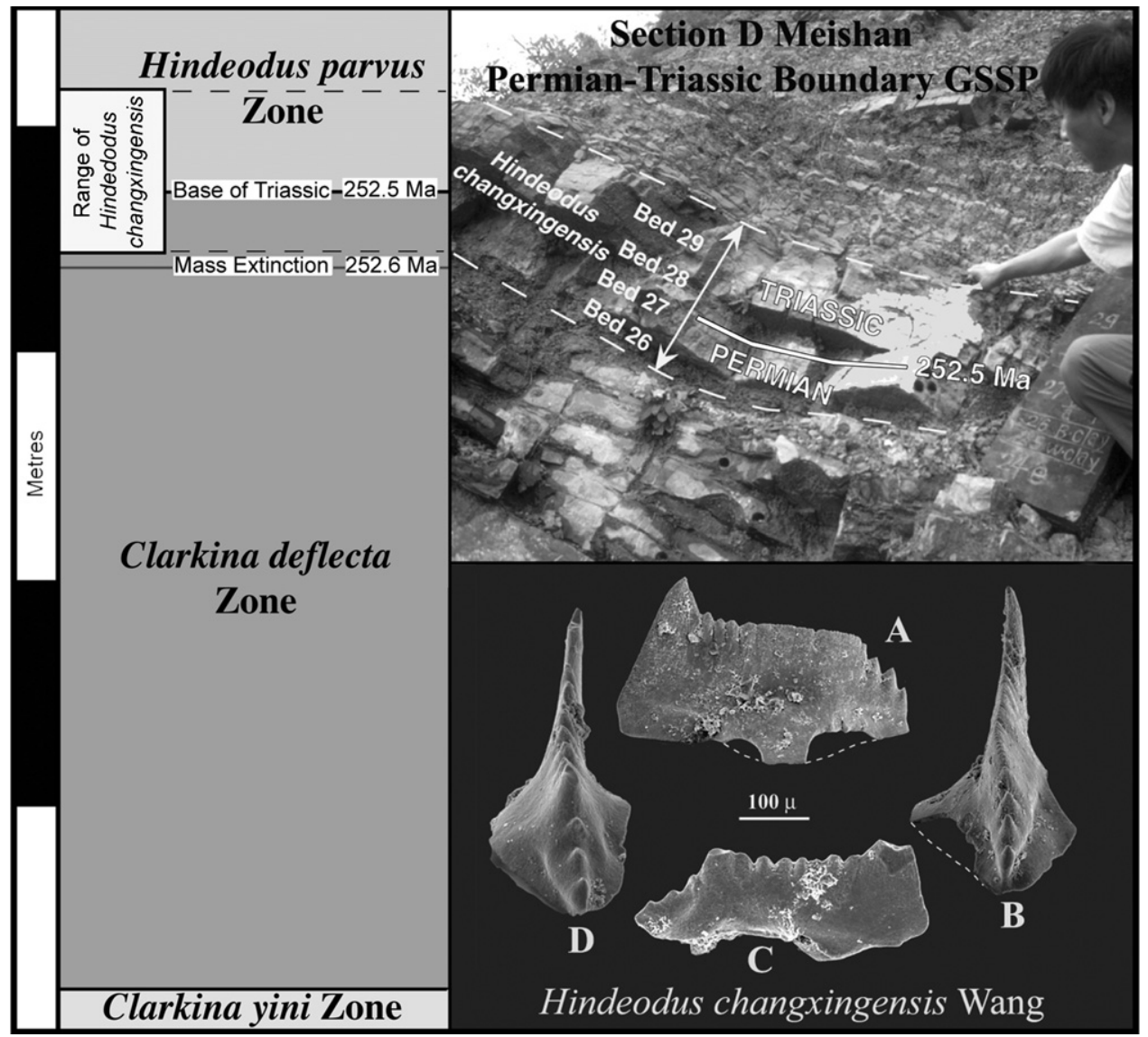

Fig. 1. Stratigraphic range of Hindeodus changxingensis Wang in relation to Permian-Triassic conodont zones and at the Permian-Triassic boundary GSSP, Meishan, China (Bed numbers are those of Yin et al., 2001). (A-D) Pa elements of Hindeodus changxingensis Wang. (A and B) Specimen CPC 39484, Meishan GSSP Section D, Bed 27. (C and D) Specimen CPC 39480, Meishan GSSP Section D, Bed 27. Isotopic ages are U-Pb zircon IDTIMS ages from Mundil et al. (2004).

tions used in this paper and supporting data for the paper can be found in Paleostrat at http://www.paleostrat.org.

\section{Systematic notes}

Illustrated specimens are reposited in the Commonwealth Palaeontological Collection (CPC) at Geoscience Australia, Canberra, Australia.

Genus Hindeodus Rexroad et Furnish, 1964.

Type species: Hindeodus cristulus (Youngquist et Miller, 1949).

Hindeodus changxingensis Wang, 1995

Fig. 2A-Z and AA-RR

1989 Anchignathodus julfensis Sweet-Dai and Zhang, pl. 53, figs. 11, 12, 21-23.

1994 Hindeodus n. sp.-Wang, 1994, pl. 1, fig. 10.

1994 Hindeodus julfensis (Sweet)—Wang, pl. 1, fig. 11.

1995 Hindeodus changxingensis n. sp.-Wang, pl. 2, figs. 14-18.
1995 Hindeodus julfensis (Sweet)—Wang. pl. 3, fig. 1.

1996 Hindeodus changxingensis Wang-Kozur, pl. 5, figs. 1, 2.

2003 Isarcicella changxingensis (Wang)_Perri and Farabegoli, pl. 1, figs. 17-19.

2004 Hindeodus changxingensis Wang-Kozur, pl. 2, figs. 7-9.

Material studied: $\quad 116 \mathrm{~Pa}$ elements (Meishan sections) $46 \mathrm{~Pa}$ elements (Zhongzhai section) 2 Pa elements (Shangsi section) $2 \mathrm{~Pa}$ elements (Selong section) 6 Pa elements (Pakistan, Sweet's specimens, 1970)

Diagnosis: Septimembrate apparatus in which the $\mathrm{Pa}$ element (Fig. 2) is carminiscaphate with a tall anterior cusp. The carina denticles over the basal cavity are of essentially uniform size but are shortest near mid-blade, and the posterior carina denticles are generally upright (not posteriorly inclined) and abruptly stepped down in height from the declination point. Carina denticles, starting from the declination point, may develop a late stage 


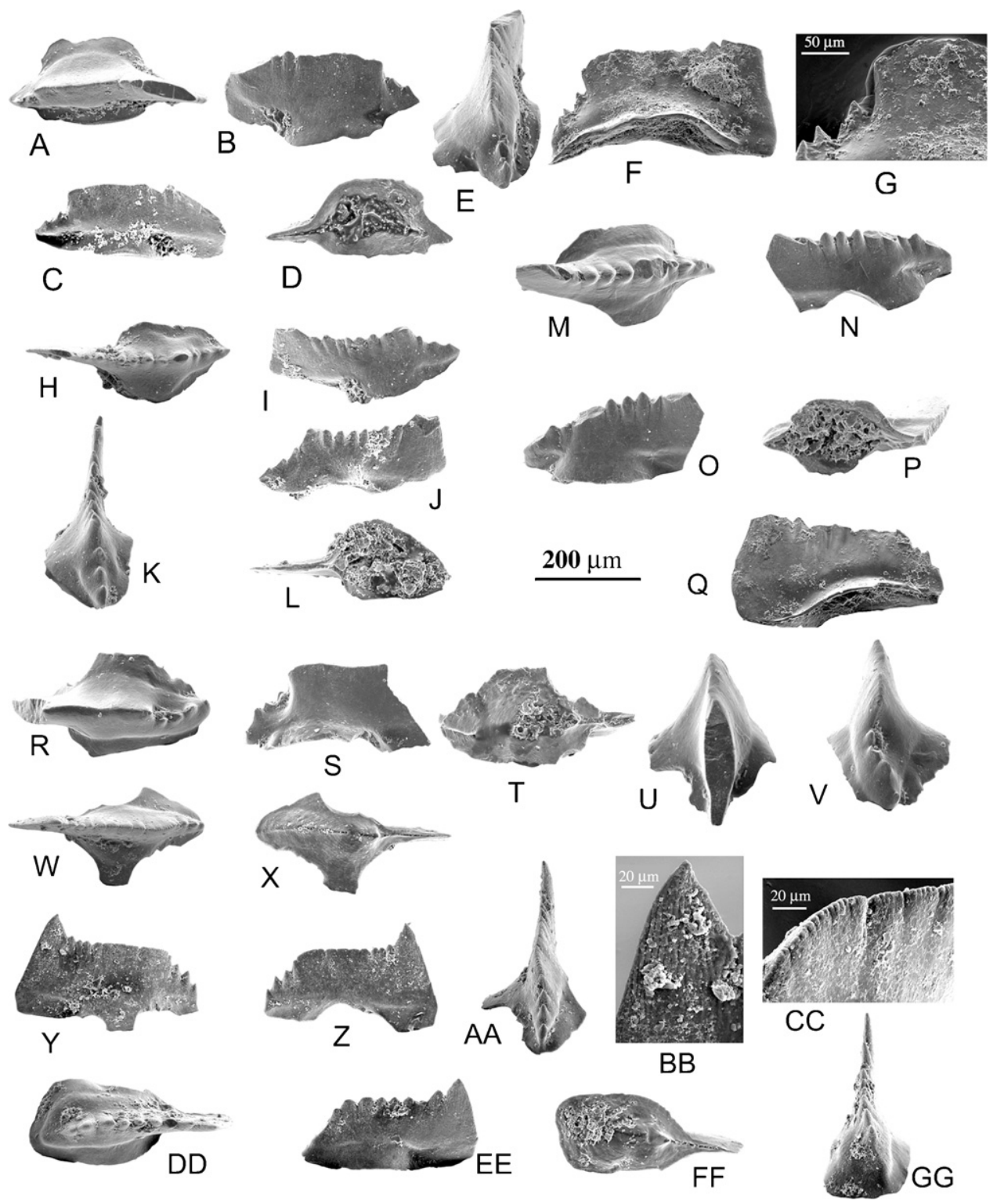

Fig. 2. Hindeodus changxingensis Wang. Pa elements. $200 \mu \mathrm{m}$ scale bar applies to all figures except G, BB and CC. A, B, C, D and E: oral, outer lateral, inner lateral, basal and posterior views of specimen CPC 39478, Meishan GSSP Section D, Bed 27. F and G: lateral view (F) and detail of carina showing typical dramatic posterior drop down of denticles (G) of specimen CPC 39479, Zhongzhai Section, sample 6405548. H, I, J, K and L: oral, outer lateral, inner lateral, posterior, and basal views of specimen CPC 39480, Meishan GSSP Section D, Bed 27. M, N, O and P: oral, outer lateral, inner lateral and basal views of specimen CPC 39481, Meishan GSSP Section D, Sample C-12, Bed 29. Q: lateral view of specimen CPC 39482, Zhongzhai Section, Sample 6405548. R, S, T, U and V: oral, inner lateral, basal, anterior and posterior views of specimen CPC 39483 , Meishan GSSP Section D, Bed 27. W, X, Y, Z, AA, BB and CC: oral (W), basal (X), lateral (Y, Z), posterior (AA), views and details of cusp showing striations (BB) and fused denticles of carina showing serrations (CC) of specimen CPC 39484, Meishan GSSP Section D, Bed 27. DD, EE, FF and GG: oral, lateral, basal and posterior views of specimen CPC 39485, Meishan GSSP Section D, Bed 27.

overgrowth that fuses progressively forward along the blade crest obscuring individual denticles. This overgrowth surface may become crenulate with a linear row of nodes forming over the denticles. The Sa element is alate and lacking a posterior process.
Remarks: Hindeodus changxingensis was derived from Hindeodus julfensis by developing a distinct reduction in the height of the post-declination point denticle sequence. Despite some superficial similarity Hindeodus changxingensis and Hindeodus julfensis are both con- 


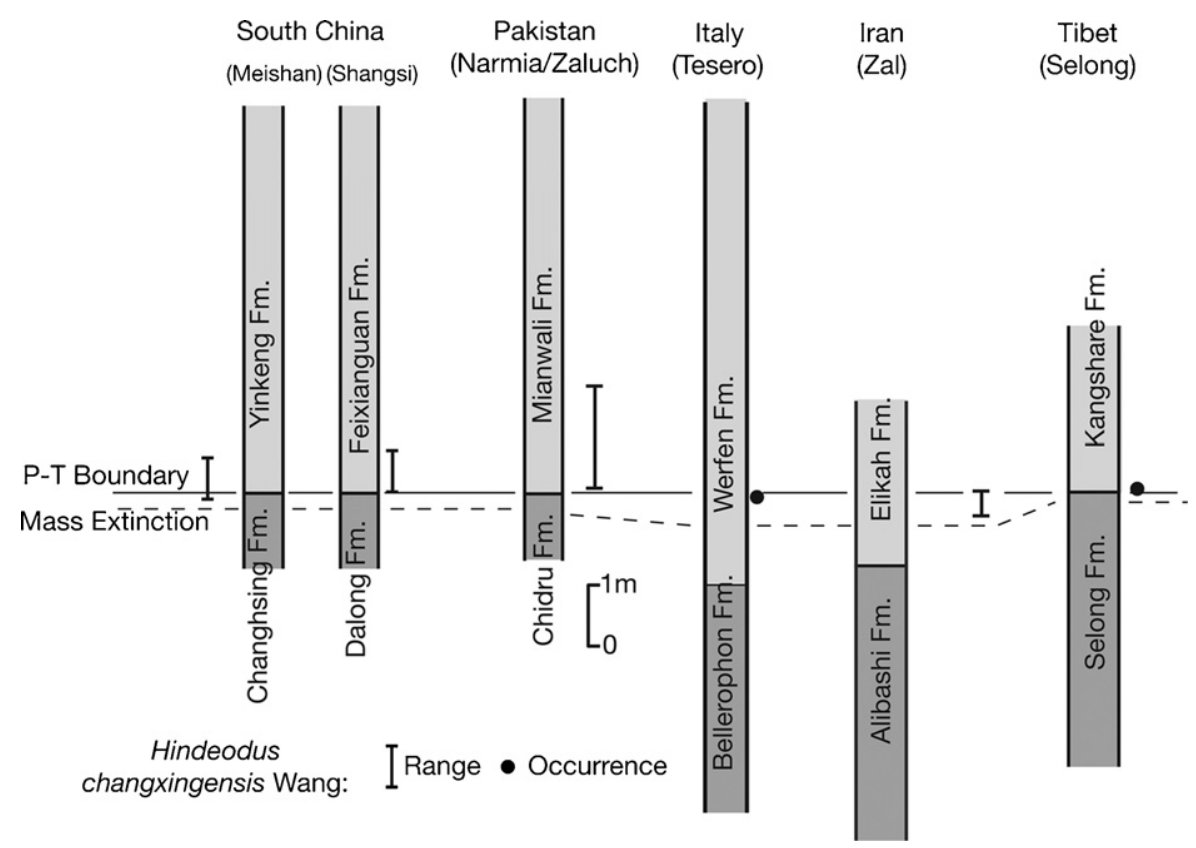

Fig. 3. Recorded occurrences and ranges of Hindeodus changxingensis Wang in P-T boundary sections in South China, Italy, Iran, Pakistan and Tibet (for sources see text).

sidered as valid species and can be distinguished using the morphology of the Pa element. In lateral view both species are similar in appearance and may have a saddle or low-point of the crest of the carina denticles between the cusp and the declination point. Both species develop a filling overgrowth on and between denticles over the posterior part of the Pa element that focuses on the declination point where the crest of the carina denticle row falls away to the posterior-basal tip. This overgrowth takes place in larger, or more mature elements, and is progressive. It starts between a single denticle pair at the declination point and extends progressively forward toward the posterior margin of the cusp. In Hindeodus julfensis this overgrowth process also extends posteriorly to include the denticles of the posterior blade on the slope. However in Hindeodus changxingensis the overgrowth does not appear to extend to the posterior blade denticles because they are separated from the carina crest by the drop-down at the declination point.

\section{Geographic and stratigraphic occurrence and significance of Hindeodus chanxingensis}

Hindeodus changxingensis is known from South China, Tibet, Pakistan, Iran and Italy, all locations within the ancient Tethys Ocean embayment of the ancient supercontinent Pangea (Figs. 3 and 4).

In South China, the species occurs in the basal Yinkeng Formation (Wang, 1995; Nicoll et al., 2002) and we record it from Bed 26 to the top of Bed 29 at the GSSP section, D Quarry, Meishan, China, and in the lower Feixianguan Formation from samples SH/C27 to SH/C28 at Shangsi, China. The species thus has its first appearance at or just above the main mass extinction level in South China and would appear to represent a dis-

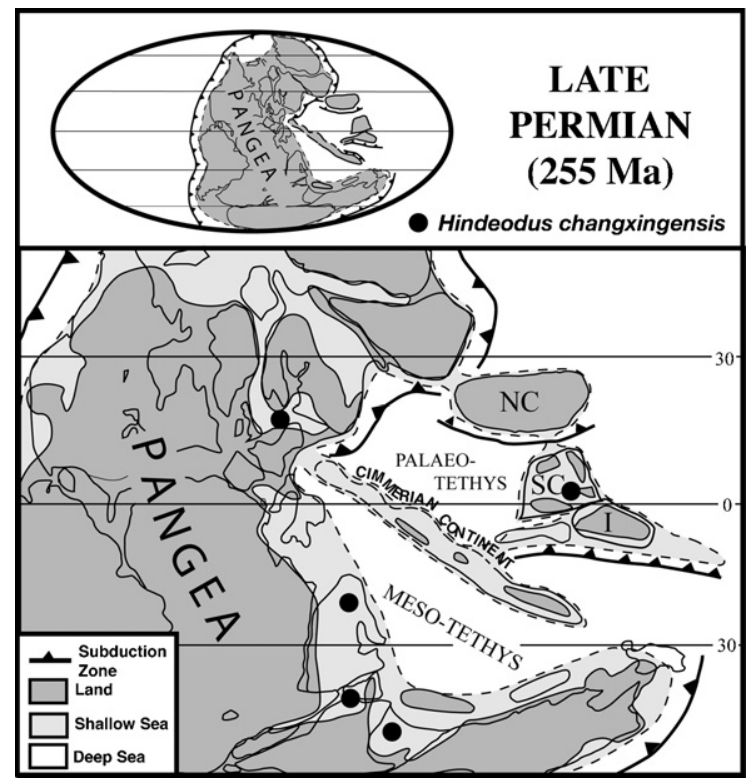

Fig. 4. Geographical occurrence of Hindeodus changxingensis Wang plotted on a Late Permian palaeogeographic map from Metcalfe (2005). 
aster speceis in the Kauffman-Erwin Model (Kauffman and Erwin, 1995).

In Italy, the species occurs near the base of the Werfen Formation, Tesero Member, Tesero section in sample TES71 at $1.3 \mathrm{~m}$ above the base Werfen Fm (Perri and Farabegoli, 2003). The first Hindeodus parvus at Tesero is at 11 metres above the base of the Werfen. Correlation with the nearby Bulla section indicates that Hindeodus changxingensis occurs essentially at the P-T boundary and again slightly above the mass extinction level.

Hindeodus changxingensis occurs in the Zal section of Iran between 37.65 and $37.90 \mathrm{~m}$. The first Hindeodus parvus is at $37.80 \mathrm{~m}$ and the mass extinction event bed is at $37.55 \mathrm{~m}$. At Abadeh in Iran, the species occurs in the upper part of the "boundary clay", upper part of $C$. meishanensis-Hindeodus praeparvus zone according to Kozur (2004). Both occurrences are in the lower part of the Elikah Formation. Again, in Iran the species appears just above the mass extinction.

In the Kathwai Member of the Mianwali Formation of the Salt Range in Pakistan, Hindeodus changxingensis has been identified by us from the Narmia Section in Sweet's (1970) samples 63TD-163, 63TD-19 and 63K1-12. Samples 163 and 19 are within $30 \mathrm{~cm}$ of (above) the boundary. Samples $1-12$ is a channel sample from the boundary to approximately $1.2 \mathrm{~m}$ above. In the Zaluch Section it occurs in sample 62T-191 $(60 \mathrm{~cm}$ above boundary).

The Tibetan occurrence of Hindeodus changxingensis is together with Hindeodus parvus in Bed 18 within the basal Otoceras Bed of the Kangshare Formation, at the Selong, Xishan Section (Shen et al., 2006) which is $15 \mathrm{~cm}$ thick and at the base of which the Permian-Triassic boundary is placed.

\section{Summary and conclusions}

In summary, Hindeodus changxingensis Wang is restricted to a narrow zone from at or just above the main end-Permian mass extinction level to a short distance above the biostratigraphically defined Permian-Triassic boundary. It is an important index fossil for studies of the Permian-Triassic mass extinction and boundary transitional horizon. Hindeodus changxingensis can be used to consistently identify the immediate post-extinction Permian-Triassic boundary interval. This has been used by us to resolve a disparity in correlation of two standard sections in China, Meishan and Shangsi. Shangsi not only has abundant zircon-bearing tuff beds through the interval but has a well defined magnetic signature. Nicoll et al. (2002) placed the P-T boundary at the first occurrence of Hindeodus parvus in that section some $4.5 \mathrm{~m}$ above the event bed. Graphic correlation and constrained optimisation correlate the P-T boundary to tens of centimetres above the event bed (Wardlaw et al., 2005), exactly where Hindeodus changxingensis occurs. In the Shangsi section, Hindeodus changxingensis is a much better guide to the greatest mass extinction and the $\mathrm{P}-\mathrm{T}$ boundary than Hindeodus parvus, the defining species of the base of the Triassic.

In general, conodonts show a tendency in intraand extra-species variation for more fusion in higher energy, shallow-water conditions. Hindeodus changxingensis appears to be the penultimate morphotype of a lineage of "humpback" Hindeodus species with a fused or overgrown carina in adult forms. Hindeodus changxingensis may truly represent an event taxa-in response to the conditions that caused the "mother of all" extinctions.

\section{Acknowledgements}

Support to I. Metcalfe from the Australian Research Council for studies of the Permian-Triassic boundary and mass extinction is gratefully acknowledged. We thank Charles Henderson and one other anonymous reviewer for their constructive reviews and comments on this paper. This paper is dedicated to the memory of Jin Yu-gan, late of the Nanjing Institute of Geology and Palaeontology, who did so much to enhance Permian studies in China and beyond.

\section{References}

Benton, M.J., 2003. When Life Nearly Died: The Greatest Mass Extinction of All Time. Thames \& Hudson Ltd., London, p. 336.

Erwin, D.H., 1993. The Great Paleozoic Crisis: Life and Death in the Permian. Columbia University Press, New York, p. 327.

Erwin, D.H., 1994. The Permo-Triassic Extinction. Nature 367, 231-236.

Jin, Y.G., Wang, Y., Wang, W., Shang, Q.H., Cao, C.Q., Erwin, D.H., 2000. Pattern of marine mass extinction near the Permian-Triassic boundary in South China. Science 289, 432-436.

Kauffman, E.G., Erwin, D.H., 1995. Surviving mass extinctions. Geotimes 14, 14-17.

Kozur, H.W., 2004. Pelagic uppermost Permian and the Permian-Triassic boundary conodonts of Iran. Part 1. Taxonomy. Hallesches Jahrbuch für Geowissenshaften 18, 39-68.

Metcalfe, I., 2005. Asia: South-East. In: Selley, R.C., Cocks, L.R.M., Plimer, I.R. (Eds.), Encyclopedia of Geology, vol. 1. Elsevier, Oxford, pp. 169-198.

Mundil, R., Ludwig, K.R., Metcalfe, I., Renne, P.R., 2004. Age and timing of the Permian mass extinctions: $\mathrm{U} / \mathrm{Pb}$ geochronology on closed-system zircons. Science 305, 1760-1763.

Nicoll, R.S., Metcalfe, I., Wang, C., 2002. New species of the conodont Genus Hindeodus and the conodont biostratigraphy of the Permian-Triassic boundary interval. J. Asian Earth Sci. 20, 609-631. 
Perri, C.M., Farabegoli, E., 2003. Conodonts across the PermianTriassic boundary in the Southern Alps. Cour. Forsch. Inst. Senckenberg. 245, 281-313.

Shen, S.Z., Cao, C.Q., Henderson, C.M., Wang, X.D., Shi, G.R., Wang, W., Wang, Y., 2006. End-Permian mass extinction pattern in the northern peri-Gondwanan region. Palaeoworld 15, 3-30.

Sweet, W.C., 1970. Uppermost Permian and lower Triassic conodonts of the salt range and Tran-Indus ranges, West Pakistan. In: Kummel, B., Teichert, C. (Eds.), Stratigraphic Boundary Problems: Permian and Triassic of West Pakistan, Special Publication 4. Department of Geology, University of Kansas, Lawrence, pp. 207-275.
Wang, C.Y., 1995. Conodonts of Permian-Triassic boundary beds and biostratigraphic boundary. Acta Palaeontol. Sin. 34, 129-151 (in Chinese, with English summary).

Wardlaw, B.R., Davydov, V.I., Sadler, P., 2005. The Permian-Triassic time slice project of CHRONOS: a progress report. In: Proceedings of the International Symposium on Triassic Chronostratigraphy and Biotic Recovery. Part 1. Program and Abstracts, vol. 33, Albertiana, pp. 86-88.

Yin, H.F., Zhang, K.X., Tong, J.N., Yang, Z.Y., Wu, S.B., 2001. The global stratotype section and point (GSSP) of the Permian-Triassic boundary. Episodes 24, 102-114. 